\title{
Status of the Western Small-footed Bat (Myotis ciliolabrum) in Alberta
}

Fish \& Wildifie Division

SPECIES AT RISK

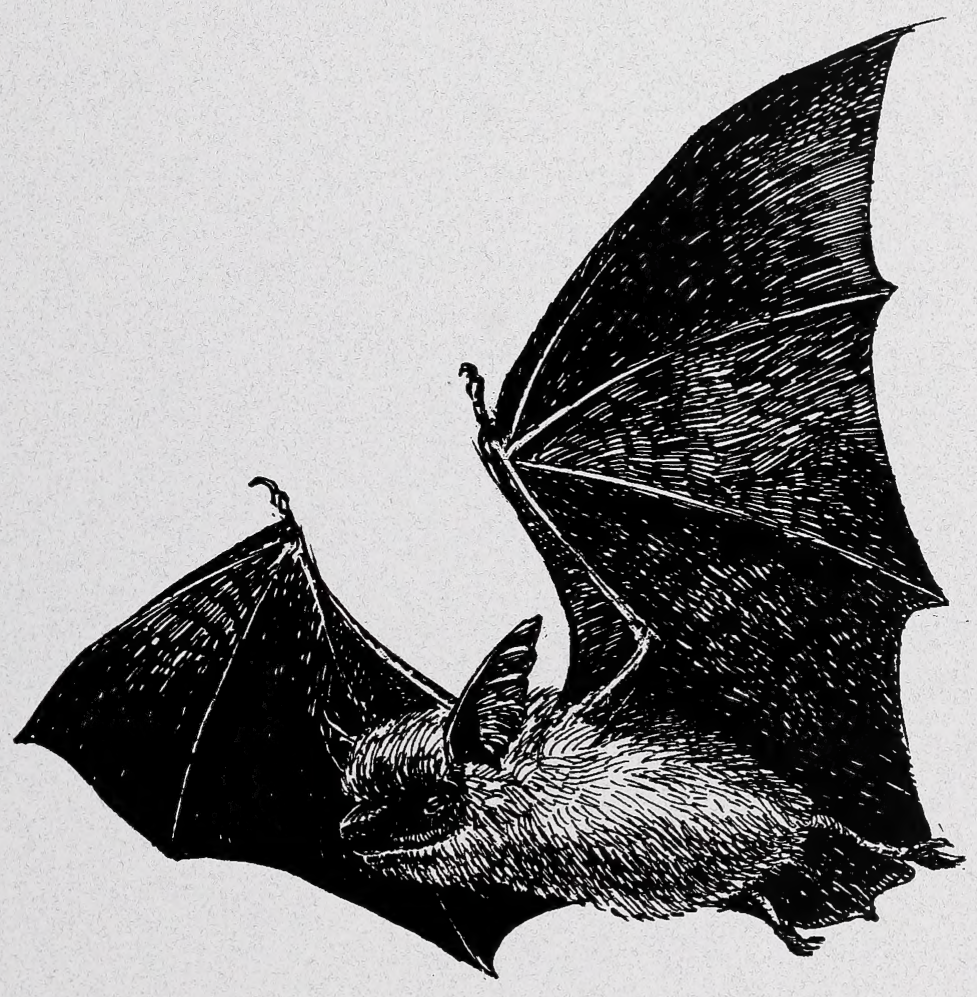

Alberta Wildlife Status Report No. 64

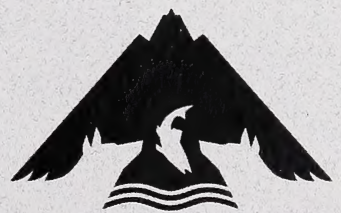

Alberta Conservation Association 



\title{
Status of the Western Small-footed Bat (Myotis ciliolabrum) in Alberta
}

\author{
Prepared for: \\ Alberta Sustainable Resource Development (SRD) \\ Alberta Conservation Association (ACA)
}

Prepared by:

\section{Cori Lausen and Tim Schowalter}

This report has been reviewed, revised, and edited prior to publication.

It is an SRD/ACA working document that will be revised and updated periodically.

Alberta Wildlife Status Report No. 64

March 2008

Published By:
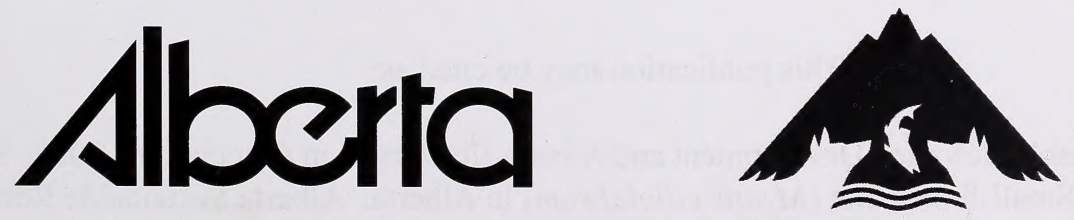

Alberta Conservation Association 
Publication No. T/163

ISBN: 978-0-7785-6569-7 (Printed Edition)

ISBN: 978-0-7785-6570-3 (On-line Edition)

ISSN: 1206-4912 (Printed Edition)

ISSN: 1499-4682 (On-line Edition)

Series Editors: Sue Peters, Robin Gutsell, Nyree Sharp and Lisa Matthias Illustrations: Brian Huffman

Maps: Nicole Hopkins

For copies of this report, visit our web site at: http://srd.alberta.ca/fishwildlife/speciesatrisk/ and click on "Detailed Status"

\section{$O R$}

Contact:

Information Centre - Publications

Alberta Sustainable Resource Development

Main Floor, Great West Life Building

9920 - 108 Street

Edmonton, Alberta, Canada T5K 2M4

Telephone: (780) 944-0313 or 1-877-944-0313

This publication may be cited as:

Alberta Sustainable Resource Development and Alberta Conservation Association. 2008. Status of the Western Small-footed Bat (Myotis ciliolabrum) in Alberta. Alberta Sustainable Resource Development, Wildlife Status Report No. 64, Edmonton, AB. 24 pp. 


\section{PREFACE}

Every five years, the Fish and Wildlife Division of Alberta Sustainable Resource Development reviews the general status of wildlife species in Alberta. These overviews, which have been conducted in 1991 (The Status of Alberta Wildlife), 1996 (The Status of Alberta Wildlife), 2000 (The General Status of Alberta Wild Species 2000), and 2005 (The General Status of Alberta Wild Species 2005) assign individual species "ranks" that reflect the perceived level of risk to populations that occur in the province. Such designations are determined from extensive consultations with professional and amateur biologists, and from a variety of readily available sources of population data. A key objective of these reviews is to identify species that may be considered for more detailed status determinations.

The Alberta Wildlife Status Report Series is an extension of the general status exercise, and provides comprehensive current summaries of the biological status of selected wildlife species in Alberta. Priority is given to species that are At Risk or May Be At Risk in the province, that are of uncertain status (Undetermined), or that are considered to be at risk at a national level by the Committee on the Status of Endangered Wildlife in Canada (COSEWIC).

Reports in this series are published and distributed by the Alberta Conservation Association and the Fish and Wildlife Division of Alberta Sustainable Resource Development. They are intended to provide detailed and up-to-date information that will be useful to resource professionals for managing populations of species and their habitats in the province. The reports are also designed to provide current information that will assist Alberta's Endangered Species Conservation Committee in identifying species that may be formally designated as Endangered or Threatened under Alberta's Wildlife Act. To achieve these goals, the reports have been authored and/or reviewed by individuals with unique local expertise in the biology and management of each species. 


\section{EXECUTIVE SUMMARY}

Western small-footed bats (Myotis ciliolabrum) are widely distributed and locally common in western North America. They are at the northern limit of their distribution in Alberta, where they are confined to prairie river valleys where badlands or clay cutbanks provide suitable roosting habitat, and adjacent riparian woodlands provide foraging habitat. Their limited distribution has resulted in a conservation ranking of Sensitive in Alberta.

Western small-footed bats are highly saxicolous (residing in rock crevices), having greater roost specificity than other residential prairie bat species, which are more often found in buildings. In Alberta, during the reproductive period, western small-footed bats roost in cavities in badland clay banks and rock crevices, selecting maternity roosts based on thermal properties.

Winter acoustic records have demonstrated overwintering in Dinosaur Provincial Park, at the Atlas Coal Mine area near East Coulee, and in Dry Island Buffalo Jump Provincial Park. The bats presumably hibernate in deep crevices.

Gene flow is diminished across long stretches of unsuitable habitat. Genetic analyses show that there is a regional Alberta population distinct from that further south in Montana. Distinct subpopulations, with restricted gene flow, occur within and between rivers in the province. Males and females both show philopatry to their natal area and males do not disperse further than females. During the summer, individuals cluster in family units.

Loss of prairie riparian cottonwood stands, used by bats as foraging habitat, may negatively affect population numbers of this species in the province. This species' dependency on riparian trees needs further investigation. Habitat loss for this species could also occur by direct flooding caused by dams on the lower reaches of the rivers in southern Alberta.

Reproductive rates of western small-footed bats are significantly lower than for big brown and little brown bats, which are two sympatric but more widespread species. Potential population isolation, limited area of distribution, and low reproductive rate make local subpopulations vulnerable to local extirpation. 


\section{ACKNOWLEDGEMENTS}

Nyree Sharp (Alberta Conservation Association [ACA]), Sue Peters (ACA) and Robin Gutsell (Fish and Wildlife Division [FWD], Alberta Sustainable Resource Development) initiated and planned this review. Ms. Sharp further provided direction throughout the preparation of the report. Reg Russell (FWD) provided the records of western small-footed bats in Alberta from the FWMIS database. Jeff Gruver, graduate student in Biological Sciences at the University of Calgary, provided data on his recent captures of western small-footed bats in the Drumheller area. David Gummer (former Curator of Mammalogy, Royal Alberta Museum) provided information on specimens in his institution. Drajs Vujnovic and Duke Hunter (Alberta Natural Heritage Information Centre [ANHIC], Alberta Tourism, Parks, Recreation and Culture) provided information on the area of badlands in southern Alberta. Lisa Wilkinson (FWD) reviewed an early draft of this report. Special thanks are due to Robert Barclay (University of Calgary) for reviewing several drafts of this report, and to the staff of the Olds College Library for providing copies of some difficult-to-locate references, and to Troy Pretzlaw for doing a great deal of the background literature search used for this report. The following provided additional pers. comm. information: Erin Baerwald, Joanna Coleman, and Jeff Gruver, graduate students at the University of Calgary; David Gummer, former Curator of Mammalogy, Royal Alberta Museum; Susan Holroyd and Matt Saunders, former graduate students at the University of Calgary; Wayne Nordstrom, ANHIC.

Preparation of this report was funded by the Alberta Conservation Association and the Fish and Wildlife Division of Alberta Sustainable Resource Development. 
Digitized by the Internet Archive in 2016 


\section{TABLE OF CONTENTS}

PREFACE iii

EXECUTIVE SUMMARY ..................................................................................... iv

ACKNOWLEDGEMENTS ..............................................................................

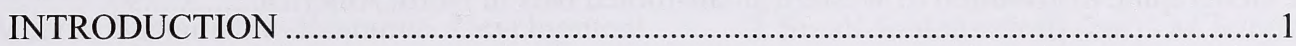

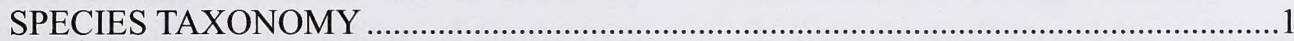

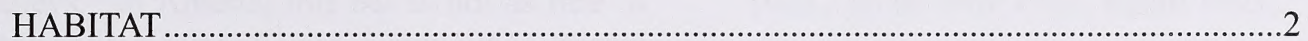

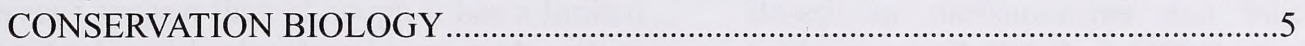

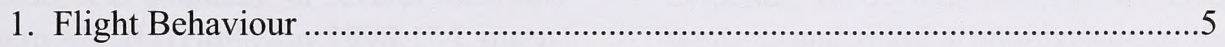

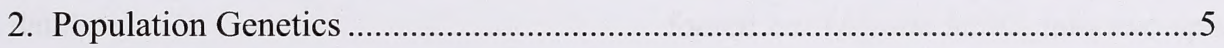

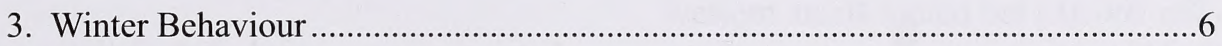

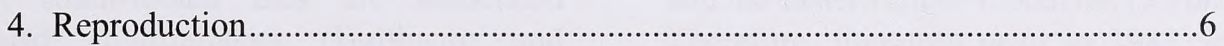

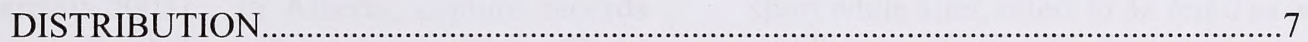

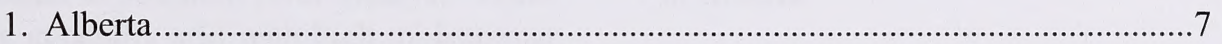

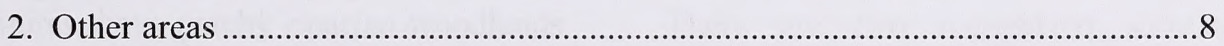

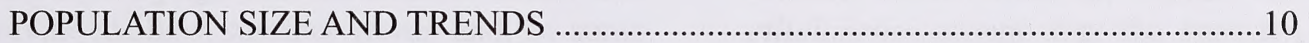

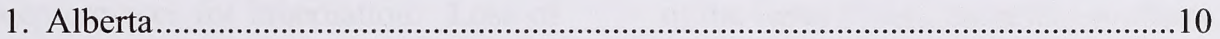

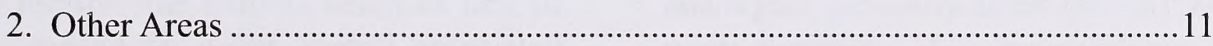

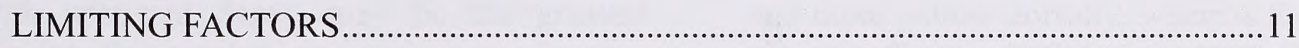

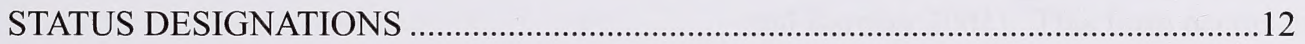

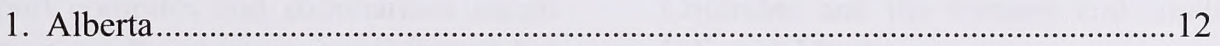

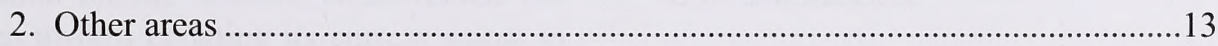

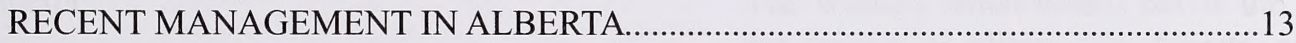

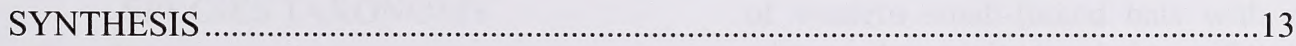

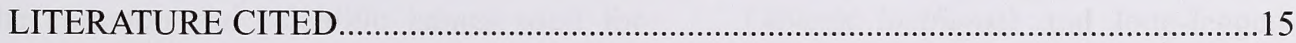

Appendix 1. Definitions of status ranks and legal designations ......................................21

Appendix 2. Percentage of total bat captures that were western small-footed bats are listed for each year. 
TABLE OF CONTENTS cont.

\section{LIST OF FIGURES}

Figure 1. Geographic distribution of capture records of western small-footed bats in Alberta 3

Figure 2. Geographic distribution of western small-footed bats in North America.............9 


\section{INTRODUCTION}

The western small-footed bat (Myotis ciliolabrum) is a member of the large and widely distributed genus Myotis within the bat family Vespertilionidae. Western smallfooted bats occur widely in western North America (Holloway and Barclay 2001). In Alberta, the species is ranked as Sensitive* (Alberta Sustainable Resource Development 2007) primarily because of its extremely limited distribution in portions of prairie river valleys. In Alberta, this bat is not as rare as once believed (Rand 1948, Soper 1964). Recent surveys suggest that, although it has a limited distribution, it is abundant in several locations in southern Alberta (Holloway 1998, C. Lausen, unpubl. data).

Western small-footed bats are associated with arid environments (Holloway and Barclay 2001). In Alberta, capture records are confined to southern river valleys. These areas are generally arid with high midsummer temperatures, have patchy riparian woodlands for bat foraging, and badlands or banks that provide shallow summer roosts and, in some areas, deep crevices for hibernation. Loss of riparian forests - the indirect result of lack of flooding caused by water control associated with upstream dams-may be the greatest threat to the populations.

This report compiles and summarizes recent information on the western small-footed bat as a step toward updating its current status in Alberta.

\section{SPECIES TAXONOMY}

The common and scientific names used for Myotis ciliolabrum have a somewhat confusing history (Foresman 2001, Holloway and Barclay

* See Appendix 1 for definitions of selected status designations.
2001), but the specific identity or distinctness of the animals found in Alberta have not been in question. The following names for this species may be encountered in the literature referring to bats from this province (major publications using the names are identified):

1. Say's masked bat - Myotis subulatus (Rand 1948, Soper 1964);

2. Small-footed myotis (bat) - M. leibii (Barbour and Davis 1969, Banfield 1974);

3. Western small-footed bat - M. ciliolabrum (van Zyll de Jong 1985, Smith 1993).

Based on measurements and biochemical evidence, van Zyll de Jong (1984) separated the western and eastern populations of the smallfooted bat (Myotis leibii) into two species, the western small-footed bat (Myotis ciliolabrum) and the eastern small-footed bat (Myotis leibii). Therefore, literature prior to 1983 and for a short while after, refers to $M$. leibii as occurring in Alberta.

There are two recognized subspecies of western small-footed bat: Myotis ciliolabrum ciliolabrum occurs over the northern portion of the Great Plains, including southern Alberta, and is pale, generally flaxen dorsally, and nearly white ventrally; M. c. melanorhinus is darker and more yellow dorsally, whereas the ventral side is buffy (van Zyll de Jong 1985, Holloway and Barclay 2001). This form occurs in British Columbia and the western and southwestern U.S. and Mexico.

The western small-footed bat is the smallest bat species in Alberta. In Alberta, confusion of western small-footed bats with members of the pale prairie populations of little brown (Myotis lucifugus) and long-legged (Myotis volans) bat is possible; the comparatively small foot (less than one-half the length of the tibia) is distinctive and probably the most reliable characteristic for those not familiar with the species or when identifying handheld individuals in the light of a head lamp ( $\mathrm{T}$. 
Schowalter, unpubl. data). The forearm lengths of little brown and small-footed bats increase from north-central Montana through southern Alberta (Lausen et al. in prep. a), however, forearm sizes differ between these species in all locations and are thus diagnostic. Further diagnostic descriptions of Alberta bat species can be found in van Zyll de Jong (1985), Pattie and Fisher (1999) and Smith (1993).

\section{HABITAT}

Throughout its range in Alberta (Figure 1), the western small-footed bat is associated with arid or semi-arid environments with cliffs, talus slopes, or clay banks. These environments tend not to be well treed in the eastern portions of the North American distribution, but in the west the species is found in open forests (Holloway and Barclay 2001). Mesic habitats are also used in the southern part of the species' range.

In Alberta, western small-footed bats are associated with the badlands (sparsely vegetated, highly eroded areas of soft sedimentary rock) along prairie rivers (Smith 1993, Holloway and Barclay 2000, Lausen et al. in prep. b). These badlands are patchily distributed along the Red Deer, South Saskatchewan and Milk rivers. Therefore, highest concentrations of western small-footed bats occur in pockets along these rivers (C. Lausen, unpubl. data). Genetic, radio-tracking, and acoustic evidence supports the notion that individuals of this species roost close to sources of water (on average $290 \mathrm{~m}$, Adams and Thibault 2006). The species is strongly saxicolous (rock-roosting), and its thermal requirements for sun-heated maternity roosts in shallow crevices and deep frost-free retreats for hibernation (Lausen and Barclay 2006, Lausen et al. in prep. b) likely limit its distribution to where those types of roosts are available along prairie river valleys.

Capture and acoustic records suggest that western small-footed bats do not wander far from rock-crevice areas of the river valleys.
Holloway and Barclay (2000) found that total bat activity (including western small-footed bats) dropped off sharply with distance from the South Saskatchewan River valley. Holloway (1998) further found that areas of the lower Red Deer River valley with extensive riparian woodlands but no badlands or large cutbanks lacked western small-footed bats, whereas they were readily captured in nearby extensive badland areas along the South Saskatchewan River. It was also found that the Myotis species made extensive use of riparian woodlands and springs in coulees as feeding areas, which also corresponded to the locations of greatest abundance of insects (Holloway and Barclay 2000).

In the southern portion of the province, there are approximately $5500 \mathrm{~km}^{2}$ of badlands habitat (D. Vujnovic and D. Hunter, pers. comm.); however, as only a portion of this habitat is along rivers with riparian feeding areas, the area occupied by the western small-footed bat would be much less. Although this species is most often captured in or near riparian cottonwood stands, its dependency on them as foraging habitat is not known. Acoustic studies suggest that this species' activity is three times higher in treed versus treeless stretches of river valley (Holloway and Barclay 2001); however, an investigation of foraging behaviour of western small-footed bats in prairie riparian areas is needed to evaluate the degree of dependency. Because riparian woodlands are disappearing - the indirect result of lack of flooding caused by upstream dams, together with agricultural factors preventing regeneration (Rood and Mahoney 1990, Cordes et al. 1997) - seemingly preferred habitat for this species will continue to decline. As long as dams are not constructed in the lower reaches of southern Alberta rivers, roosting habitat should remain available for this species. Some badlands features have already been flooded in Alberta by the Oldman Dam, and just across the border in Montana by the Fresno Dam. It is not known how much of an impact, if any, this had on western small- 


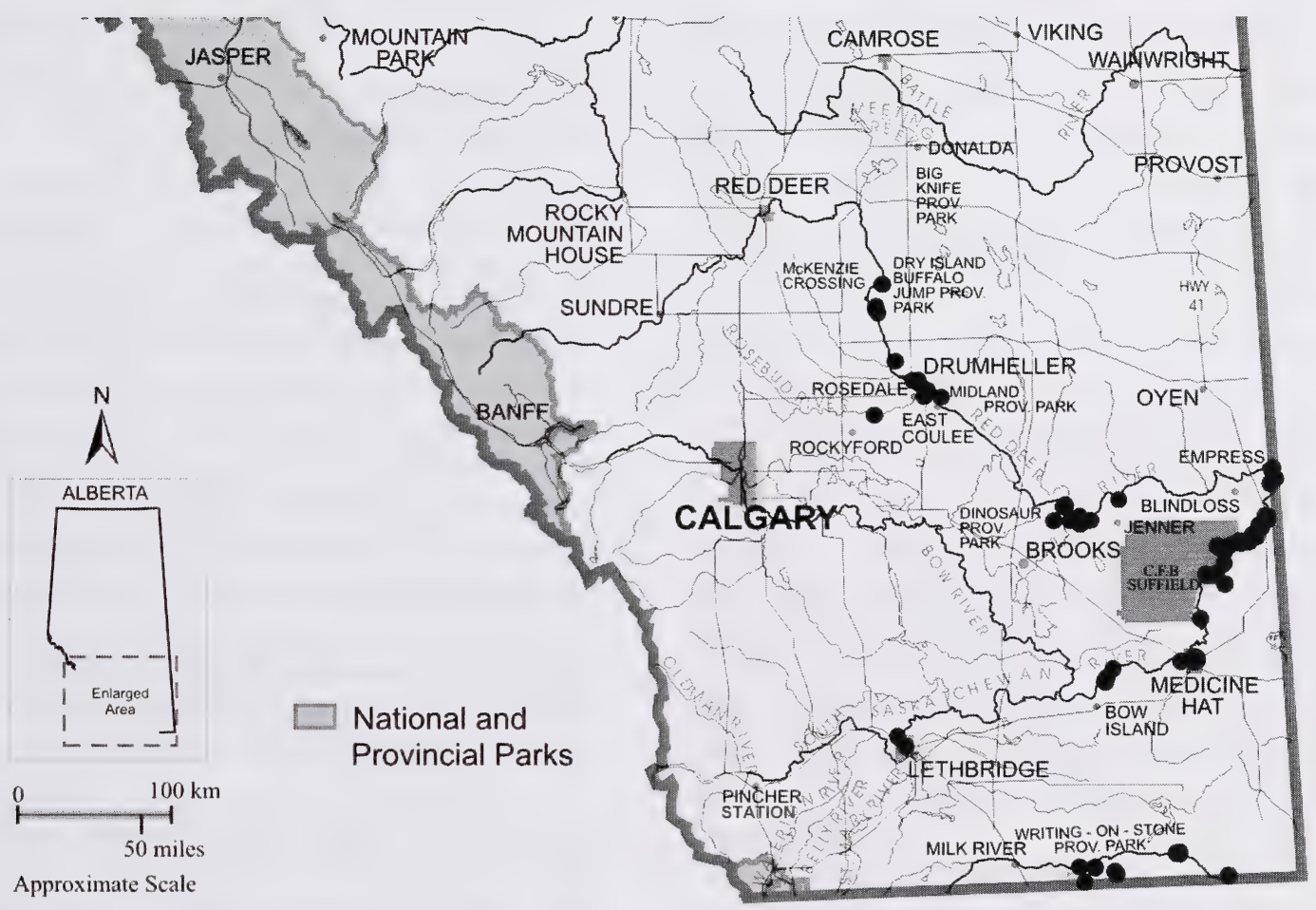

Figure 1. Geographic distribution of capture records of western small-footed bats in Alberta. Data sources: Alberta Sustainable Resource Development (2005), Jones (1974), Lausen (2006), Rand (1948), Royal Alberta Museum (2007), J. Gruver (pers. comm.) and J. Coleman (pers.comm.). Possible record in southwest foothills reported by Collister and Hunt (1990) is not shown. 
footed bats given the lack of pre-dam surveys. Small sections of roosting and foraging habitat have been destroyed through bridge, road and pipeline construction, and developments associated with cities and industry (e.g., near Medicine Hat and Lethbridge).

Extensive badland formations are not the only river valley features that provide suitable roosting habitat for this species. Captures in the Empress area near the Saskatchewan border, and near Bow Island (C. Lausen, unpubl. data; Figure 1), where extensive badlands are lacking, provide evidence that clay cutbanks provide suitable habitat as well. Captures in these areas occurred near clay banks but not in areas with grassy slopes (C. Lausen, unpubl. data).

Holloway (1998) and Lausen et al. (in prep. b) examined roosts of western small-footed bats in the badlands along the South Saskatchewan River. Both found that this species roosts predominately in small "mudstone" erosion holes ( $68 \%$ of roosts; Lausen et al. in prep. b), which are eroded crevices in solidified mud/ clay rich in bentonite (Lausen 2001 and 2007). Mudstone roosts tend to have small openings (Holloway 1998, Holloway and Barclay 2001, Lausen et al. in prep. b), are shallow, face south/southeast for good solar insolation, are generally in banks of low/gentle slope, and are on average about $1.3 \mathrm{~m}$ above level ground (Lausen 2007). However, western smallfooted bats were also found roosting in boulder cracks and cavities created by piles of rocks on the ground (Lausen et al. in prep. b), and in large "water erosion cracks descending into the ground on relatively flat slopes" (Holloway 1998, p. 38). Roosting by the species in these latter "ground roosts" has not been described elsewhere. Mudstone provides better insulation than denser rock (Lausen and Barclay 2002), and diurnal roosting in mudstones by western small-footed bats has been widely observed (Merriam 1886, Koford and Koford 1948, Quay 1948, Barbour and Davis 1969, Tuttle and Heaney 1974, Robbins et al. 1977, Garcia et al. 1995, Holloway 1998, Navo et al. 2002). Reproductive females in South Dakota badlands use shallow south-facing mudstone erosion holes with similar properties to those described for Alberta (Tuttle and Heaney 1974). Western small-footed bats use small natural caves as night roosts in Alberta (Schowalter and Allen 1981, Holloway 1998, C. Lausen, unpubl. data) and elsewhere (Holloway and Barclay 2001). Neither Holloway (1998) nor Lausen et al. (in prep. b) tracked radio-tagged western smallfooted bats to roosts in trees, despite there being large trees available in the study areas.

Holloway (1998) reported roost emergence counts of 2 to 35 individuals. The latter number, if all the bats observed were western smallfooted bats, would indicate one of the largest groups observed for the species. This species has occasionally been observed roosting with other species (C. Lausen, pers. obs.), therefore emergence counts cannot always be assumed accurate. Lausen et al. (in prep. b) found reproductive females typically roosted alone or in pairs, but were found in maternity colonies as large as five individuals. In South Dakota, 10 of 12 roosts had only one bat (Tuttle and Heaney 1974).

Individuals switch roosts frequently, usually daily (Lausen 2007), but remain in a small "roost area." Home range size for western small-footed bats is not known with certainty; however, recorded movements are short. For radio-tagged bats, mean distance between successive roosts by individuals was $45 \pm 6 \mathrm{~m}$ along the South Saskatchewan River (range $6.4 \mathrm{~m}-106 \mathrm{~m}$ ). The mean distance between the mist-net capture location and first roost for an individual was $146 \pm 23 \mathrm{~m}$ (range $4 \mathrm{~m}$ $-580 \mathrm{~m}$ ). Banding recapture records from the South Saskatchewan River suggest location fidelity in both sexes and all ages (Lausen 2007). 
Buildings and other artificial structures are probably of trivial importance to western smallfooted bat populations, given that only rarely have individuals been reported from humanmade structures (Stephens 1945, Dalquest 1948, Koford and Koford 1948, Davis and Cockrum 1963, Jones 1964, Barbour and Davis 1969, Swenson and Shanks 1979, Hendricks et al. 2005); in Alberta, there is only one record of a western small-footed individual in a building (Schowalter and Allen 1981).

\section{CONSERVATION BIOLOGY}

1. Flight Behaviour. - Western small-footed bats are erratic, slow flyers (Dalquest 1948, Schowalter and Allen 1981) and do not move far seasonally or during their lifetime (Lausen 2007). These bats are most frequently captured along low cliff faces, near bushes and trees (Fenton et al. 1980, C. Lausen, unpubl. data), or over small bodies of water (Hardy 1941, Kuenzi et al. 1999). Woodsworth (1981) observed that individuals tend to follow a repeating path while foraging. Western small-footed bats are early flyers, emerging soon after sunset (Fenton et al. 1980) and often concentrating their early foraging activity around vegetation along the edges of rock faces (Fenton et al. 1980, C. Lausen, unpubl. data). Capture efforts by Lausen (2007) suggest that female western small-footed bats may use night roosts more than other species as they are captured less often in the middle of the night, compared to other prairie species. Studies of physiological and foraging patterns are needed to understand why this might occur.

2. Population Genetics. - The patchiness of suitable roosting habitat along prairie rivers has produced a patchy distribution of this species (C. Lausen, unpubl. data). Lausen (2007) studied the degree of connectivity among patches of individuals in a genetic analysis of western small-footed bats from locations along the Red Deer, South Saskatchewan, Milk and Missouri rivers. The research determined that gene flow is limited by distance and by topography. Gene flow occurred along most rivers between sites that were close (less than $150 \mathrm{~km}$ ) with suitable habitat between sites; the one exception to this was on the South Saskatchewan River where the Bow Island subpopulation showed limited gene flow with the subpopulation near C.F.B Suffield. One western small-footed bat was captured in Medicine Hat (S. Holroyd, pers. comm.) and one just outside the city (C. Lausen, unpubl. data), but in general, this species seems uncommon in the Medicine Hat region, despite suitable mudstone habitat.

Between-river gene flow is limited in this species, and hierarchical genetic analysis revealed that western small-footed population structure reflects river topography. Neither males nor females move far to mate, and males, like females, are philopatric to their natal area to a larger extent than other prairie bat species (Lausen 2007). Males and females generally stay within a river and river system to mate and hibernate, but then return to their natal areas in the summer where males, as evidenced by their mitochondrial DNA (mtDNA), roost close to their female relatives. Closely related females roost together (all roost-mates are of a single matriline), or within metres of each other, producing small clusters of related males and females along the rivers (Lausen 2007). Each site sampled by Lausen (2007) had at least one unique mitochondrial DNA haplotype, suggesting the loss of bats in one stretch of the river would cause the loss of a set of unique genes from the population.

Breeding seems to preferentially occur between clusters of individuals that are in close proximity along a river valley (less than 150 $\mathrm{km}$, Lausen 2007). Genetic results suggest that although gene flow is primarily within rivers and river systems, genetic exchange also occurs along appropriate habitat corridors (e.g., stream banks or long coulees) that exist between rivers (Lausen 2007). Western small-footed bats are more genetically structured than little brown 
and big brown bats in the prairies, likely due in part to small size (relatively poor flight ability) and roost specificity (Lausen 2007).

Dispersal is the moving of individuals away from their place of birth (Ricklefs 1990). Average dispersal distance is low in this species (male dispersal distance $70 \mathrm{~km}-134 \mathrm{~km}$; Lausen 2007), in contrast to other bat species in the prairies (big brown bats $460 \mathrm{~km}$, little brown bats $600 \mathrm{~km}$; Lausen 2007). Mammals tend to have male-biased dispersal (Greenwood 1980 ), but that is not the case for western smallfooted bats (Lausen 2007). Where mating takes place is not known, but as more prairie hibernation areas are found for this species, a better understanding of gene flow may ensue.

Mitochondrial DNA analyses show that there is limited and perhaps no dispersal of female or male western small-footed bats between Alberta and the Missouri River of Montana. Nuclear gene flow supports limited mating between Missouri and Alberta individuals, suggesting that some barrier may exist to hinder movement of individuals between the Milk and Missouri rivers. Lausen (2007) points to a long $(500-\mathrm{km})$ stretch of river valley between the Milk and Missouri rivers where no suitable western small-footed bat roosting habitat exists. Interestingly, Lausen's sampling sites on the Milk and Missouri rivers are only approximately $60 \mathrm{~km}$ apart, reinforcing the finding that western small-footed bats tend to be restricted to staying within river valleys, and that stretches of unsuitable roosting habitat can impact connectivity between groups of individuals.

\section{Winter Behaviour. - Western small-footed} bats have been detected in winter in Dinosaur Provincial Park, at the Atlas Coal Mine area near East Coulee (Lausen and Barclay 2006), and in Dry Island Buffalo Jump Provincial Park (Lausen 2006), providing evidence that the animals hibernate locally. Travel between summer and winter roosting areas is likely less than $200 \mathrm{~km}$, based on genetic results (Lausen 2007). Presumably western small-footed bats hibernate in deep crevices in riparian badlands as do big brown bats (Eptesicus fuscus, Lausen and Barclay 2006). Western small-footed bats have been observed widely, although in small numbers, to hibernate in caves and mines throughout most of its distribution (Holloway and Barclay 2001). Abandoned mines might be used as hibernacula in the East Coulee region.

Bats arouse periodically during hibernation and may venture out of their roosts in search of water (Lausen and Barclay 2006). Periodic arousal uses energy reserves and because these reserves are limited by lack of insect food during winter, it is not known how many arousals individuals can and do make throughout the winter.

4. Reproduction. - The life-cycle of western small-footed bats appears to be similar to those of many other Myotis species in North America. Mating takes place in the fall or winter, before or during hibernation. Reproductive rates of western small-footed bats are low. Generally, a single offspring is born in June or July (Barbour and Davis 1969, Holloway and Barclay 2001); only single young have been observed in Alberta (C. Lausen, unpubl. data). One exception was an occurrence of twins inferred from an observation of two young with a single female in South Dakota (Tuttle and Heaney 1974). Although relatively few bats have been banded in areas where sampling occurred over several years, recapture of several female western small-footed bats on the South Saskatchewan River demonstrated that adult females do not reproduce each year (C. Lausen, unpubl. data). In southern Alberta, after the onset of lactation, the overall ratio of reproductive to non-reproductive adult female western small-footed bats was 197:154 (56.1\% reproductive, 2001 - 2005; Lausen 2007). This is significantly lower than the reproductive rates of $78.3 \%(227 / 290)$ and $74.9 \%$ (311/415) for big brown and little brown bats, respectively, also from southern Alberta in 2001-2005 
(Lausen 2007). Kuenzi et al. (1999) found only $41.2 \%$ of 51 adult female western small-footed bats in Nevada to be reproductive, suggesting that a low reproductive rate is typical for this species. Although longevity is not known for this species, bats tend to be long-lived, and record ages for other species found in southern Alberta range from 19 - 34 years (Wilkinson and South 2002); long lifespan presumably offsets their low reproductive rates (Barclay et al. 2004).

Outside of Alberta, sex ratios of captured adult western small-footed bats have favoured males (Bogan et al. 1996; Cryan et al. 2000; Hendricks et al. 2004; Hendricks and Maxell 2005). In Montana, just across the Alberta border on the Milk River near Havre, the ratio of males: females was 59:2, despite great effort to find females (C. Lausen, unpubl. data). In contrast, in Alberta, Lausen (unpubl. data) found that the sex ratios are closer to 50:50, with males (406) captured slightly less than females (457). The extreme sex bias in some prairie capture locations (Montana, South Dakota) is not understood. Sex ratios may reflect differences in thermal or food resources, making some areas better suited to one sex over the other (Cryan et al. 2000, Grindal et al.1999).

\section{DISTRIBUTION}

1. Alberta. - In Alberta, the western smallfooted bat is known from the prairie river valleys and associated coulees of the South Saskatchewan, Red Deer and Milk river basins (Figure 1). Captures have primarily been made in four regions in Alberta: Dry Island Buffalo Jump Provincial Park south to East Coulee on the Red Deer River (Alberta Sustainable Resource Development 2005, Lausen 2006, Lausen and Barclay 2006; J. Gruver, pers. comm.); Dinosaur Provincial Park from Steveville through to the Jenner Crossing (Jones 1974, Schowalter and Allen 1981, Alberta Sustainable Resource Development 2005, C. Lausen, unpubl. data) in the Red Deer
River; from the Saskatchewan border near Empress to approximately half the distance to Medicine Hat along the South Saskatchewan river valley (Holloway 1998, C. Lausen, unpubl. data, Alberta Sustainable Resource Development 2005); from the eastern crossing of the international border on the Milk River, upriver (west) to Writing-on-Stone Provincial Park (Soper 1964, Smith 1993, Alberta Sustainable Resource Development 2005, M. Saunders, pers. comm., C. Lausen, unpubl. data). Some western small-footed bats have also been captured on the South Saskatchewan River north of Bow Island. Here it took several months of nightly mist-netting to capture the same number of western small-footed bats as could be captured in a single night of sampling downriver near the Saskatchewan border (C. Lausen, pers. comm.). In 2007, a single western small-footed bat was captured near Rockyford on the Rosebud River, a tributary of the Red Deer River (J. Coleman, pers. comm.).

What appears to be suitable badlands habitat occurs in the Red Deer River valley north of Dry Island Buffalo Jump, along the Battle River in Big Knife Provincial Park and upriver along Meeting Creek near Donalda. However, surveys in those locations resulted in no captures or auditory detection of western smallfooted bats, though the portions of the Red Deer River valley north of Dry Island Buffalo Jump Provincial Park should be surveyed further (Lausen 2006). Capture effort and acoustic monitoring along Meeting Creek were sufficient to suggest that western small-footed bats are rare or absent there (Appendix 2).

Many areas of southern Alberta have not been surveyed for this species. For example, well-developed badlands habitat and riparian woodlands continue further downstream of East Coulee on the Red Deer River, but it has not been surveyed for bats. Suitable western small-footed bat habitat exists along stretches of the Belly, Old Man, Waterton and St. Mary rivers (C. Lausen, pers. obs.), suggesting 
this bat may be found south and west of Lethbridge. However, with the exception of a small stretch of the Old Man River north of Pincher Station (just northwest of the town of Pincher Creek), rivers south and west of Lethbridge have not been surveyed; despite the presence of cutbanks in the area near the Old Man Reservoir, substantial netting efforts in 2006 and 2007 found no western small-footed bats (more than 200 bats captured in total, Appendix 2; E. Baerwald pers. comm.). There are several specimens of western small-footed bats recorded as being from near Lethbridge (Figure 1) in the collections of the Royal Alberta Museum in Edmonton (Royal Alberta Museum 2007; D. Gummer pers. comm.), but some of these specimens may have been submitted for rabies testing to the Animal Diseases Research Institute near that city (T. Schowalter, pers. obs.), making their location of origin uncertain. There is a single report of a western smallfooted bat from the southwestern foothills (Collister and Hunt 1990); unfortunately, that record was not accompanied by photographs or measurements, and it did not appear that the authors were aware that little brown bats in southern Alberta are very pale coloured, similar to western small-footed bats (Smith and Schowalter 1979, Lausen 2006). Few surveys have been conducted on the Bow River; in 2006 and 2007, mist-netting along the Bow River south and east of Calgary produced no captures of western small-footed bats (J. Coleman, pers. comm.).

The extent of occurrence for this species can be roughly estimated as $50188 \mathrm{~km}^{2}$ using a convex hull polygon; however, this estimate contains areas outside of the river valleys where this species has not been found, and would be considerably smaller if those areas were removed. The total area that western smallfooted bats occupy in Alberta is unknown. Although it is assumed that the species is essentially confined to prairie river valleys, little capture effort has taken place outside of the badlands areas. A rough estimate of the area of occupancy ranges from $276 \mathrm{~km}^{2}$ (overlaying a $2-\mathrm{km}$ by $2-\mathrm{km}$ grid on existing locations and multiplying the number of occupied grid cells by the area of each cell) to $1250 \mathrm{~km}^{2}$ (if considered as several strips along prairie river valleys). The latter number assumes that the "distribution" is $3 \mathrm{~km}$ wide - an approximation of valley and foraging area width - along $80 \mathrm{~km}$ of the upriver part of the lower Red Deer River, $95 \mathrm{~km}$ along the Milk River and $170 \mathrm{~km}$ of the South Saskatchewan River. A width of $5 \mathrm{~km}$ was assumed for an additional $43 \mathrm{~km}$ in the downriver part of the lower Red Deer River around Dinosaur Provincial Park. Most of these areas consist of well-developed badlands terrain; however, approximately $112 \mathrm{~km}$ $\left(336 \mathrm{~km}^{2}\right)$ along the South Saskatchewan River from about half way between the Saskatchewan border and Medicine Hat upstream to Bow Island consists of fragmented habitat with varying gaps between outcrops and large cutbanks. In addition, some small stretches of the Milk River valley included here may not have suitable habitat for western small-footed bats.

It is likely that the overall species distribution does not differ substantially between summer and winter, although during winter months western small-footed bats are likely clustered in fewer areas along the rivers, where pockets of deep crevices allow hibernation.

2. Other Areas. - The western small-footed bat is widely distributed in western North America (Holloway and Barclay 2001) ranging from British Columbia, Alberta, and Saskatchewan, to south-central Mexico (Figure 2). The species does not occur along the Pacific coast of Washington, Oregon, and most of California. Where it does occur, it ranges from $300 \mathrm{~m}$ to $3300 \mathrm{~m}$ in altitude (Nagorsen and Brigham 1993).

Western small-footed bats occur in jurisdictions neighbouring Alberta, including Saskatchewan, British Columbia, and Montana. The only 


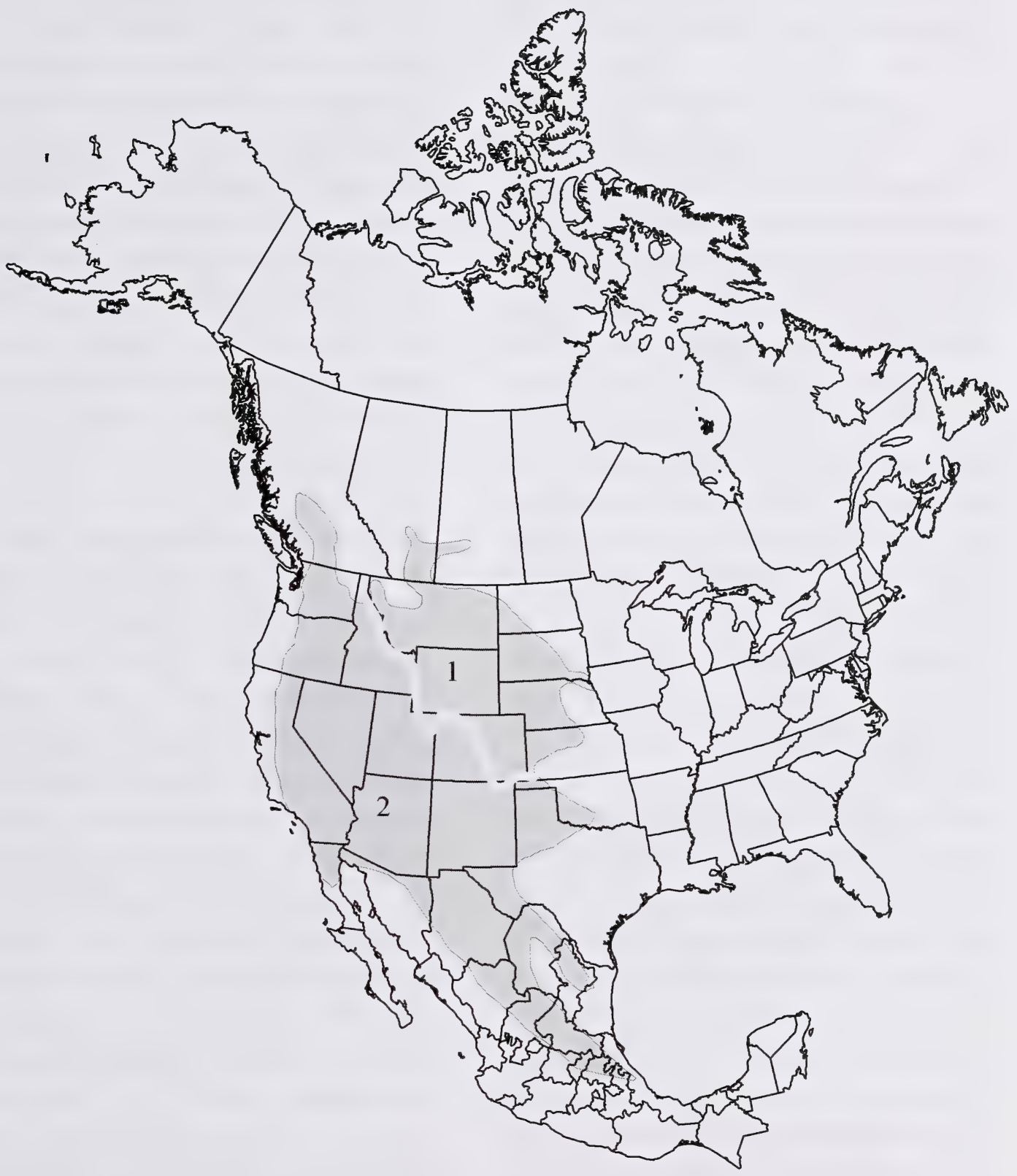

Figure 2: Geographic distribution of western small-footed bats in North America (adapted from Holloway and Barclay 2001 with modifications from Foresman [2001] and data compiled from this review). 1. M. c. ciliolabrum; 2. M. c. melanorhinus. 
two published records from Saskatchewan are from the west-central portion of the South Saskatchewan River drainage (Beck 1958; Nero 1958, 1959). Suitable eroded banks and badlands terrain occur widely along the South Saskatchewan River in Saskatchewan and are likely to support western small-footed bats (C. Lausen, pers. obs.). In British Columbia, the species has long been recognized from the Okanagan and Similkameen valleys and is known further north from the Chilcotin River and Williams Lake (Nagorsen and Brigham 1993). Western small-footed bats occur widely in Montana (Foresman 2001, Hendricks and Maxell 2005). Winter records of hibernating western small-footed bats in neighbouring jurisdictions include a few individuals in a coal mine in south-central Montana (Swenson 1970) and in caves and mine adits (entrances) in the Okanagan and Williams Lake regions of British Columbia (Nagorsen and Brigham 1993).

\section{POPULATION SIZE AND TRENDS}

1. Alberta. - There are insufficient data for estimating population size or evaluating longterm trends of Alberta populations of western small-footed bats. Until the 1970s, there were only two records of the species from Alberta (Rand 1948, Soper 1964). Soper's (1964) assessment of the species as "rare" likely stemmed from limitations of collecting activities. Changes in sampling methodologies over time have made it difficult to compare current with historic abundance for many bat species (Pierson 1998). With the advent of mist-netting, enough captures were made in the 1970s near Jenner (Jones 1974), west of Rumsey (T. Schowalter, pers. obs.), and Dinosaur Provincial Park (Schowalter and Allen 1981) to suggest that the species was relatively abundant in relation to other bat species in those areas. As well, there were a number of submissions of rabies-suspect specimens from locations in the south of the province (T. Schowalter, pers. obs.).
Research that has focused on prairie bats, based in the R. Barclay lab at the University of Calgary, has demonstrated that western small-footed bats are common in certain areas in prairie river valleys. Along badlands areas of the South Saskatchewan River, Holloway (1998) found the western small-footed bat to be the most frequently captured species at rates of $0.37,0.21$ and 0.16 bats/mist-net-hour at sites along treed river stretches, in coulees and at springs, respectively. Unfortunately, comparable capture rate data are not available for other areas for that period. Similarly, capture rates in this area at later dates are not comparable given that general mist-netting was not conducted again; rather, certain bat species were targeted for various research projects.

The proportion of western small-footed bats captured in Alberta from 2001 to 2006 relative to total bat captures provides a general idea of the relative abundance of the species in different regions (Appendix 2; C. Lausen, unpubl. data). However, because certain species were being targeted for different studies during most of these capture sessions (e.g., strategic net placement and net heights to match species of interest), only estimates of relative abundance can be made. Western small-footed bats seem to be most abundant in Dinosaur Provincial Park and along the lower reaches of the South Saskatchewan and Milk rivers. It is least abundant on the edges of its known distribution: in the north, upriver of Drumheller on the Red Deer River, and in the south in the Writing-onStone Provincial Park region of the Milk River (Appendix 2).

The life histories of bats (i.e., low reproductive rates, high overwinter juvenile mortality; Barclay et al. 2004) make their populations vulnerable to declines, and therefore being able to monitor trends in populations of bats is highly desirable (O'Shea and Bogan 2003a). Bats in North America tend to roost concealed and are therefore cryptic, making them difficult to census. When bats aggregate in moderate 
numbers, emergence counts and roost counts can provide rough estimates of local population numbers (Kunz 2003). Species that roost in small groups or alone in crevices (overdispersed bats) pose the greatest challenge for censusing (Kunz 2003) - western small-footed bats fall into this category. The lack of standard protocols to collect comparable data over time limits estimation of bat populations across the continent (O'Shea and Bogan 2003b). There are many challenges to estimating bat populations and monitoring trends, and much hope relies on improved future technology, such as better mark-resight techniques that do not require recapture (O'Shea and Bogan 2003b). Based on surveys by Lausen (unpubl. data, 2007) and others it is clear that there are at least four areas in the province where this species is relatively abundant (clusters described above). Markrecapture efforts in these areas may provide an estimate of abundance, but currently no such numbers are available.

2. Other Areas. - Western small-footed bats are common in badlands, semi-arid and desert areas in western North America (Holloway and Barclay 2001). Nowhere are there sufficient data to support evaluation of trends in numbers. They have been noted to be the most frequently captured bat species in Badlands National Park, South Dakota (Farney and Jones 1980, Bogan et al. 1996), in west-central Nevada (Kuenzi et al. 1999), and in the desert of eastern Washington (Dalquest 1948). In Montana, the species has been thought to be uncommon but widely distributed (Foresman 2001, Hendricks and Maxell 2005). As in Alberta, western smallfooted bats are locally abundant in badlands regions of prairie rivers in Montana (C. Lausen, unpubl. data); however, the species is also found in treed areas in the western part of the state (Hendricks and Maxell 2005). Moderate numbers are known from the more arid regions of southern British Columbia (Nagorsen and Brigham 1993).
There are too few records to establish abundance in Saskatchewan (Nero 1958, 1959; Beck 1958, C. Lausen, unpubl. data).

\section{LIMITING FACTORS}

In Alberta, western small-footed bats appear to be confined to crevice-rich areas in prairie river valleys. Summer clusters are patchy and genetic analyses suggest there are several local populations separated by regions of poor habitat. Dispersal distances and reproductive rates are low, suggesting a subpopulation of this species is unlikely to rebound from a catastrophic event. Any threat to rock-roosting habitat within river valleys threatens this species; destruction of large areas of roosting habitat (such as flooding from dams) has the potential to not only isolate populations but to reduce the likelihood of a population being re-established by immigration should one be lost. The proposed Meridian dam would have flooded a large section of the South Saskatchewan River, including one of the four major areas of western small-footed bat habitat in the province. However, this dam was deemed unfeasible (Government of Alberta 2002).

Other than direct flooding from potential construction of dams downstream, there appear to be few developments potentially affecting most of the river-valley badlands terrain in southern Alberta. Holloway and Barclay (2000) considered that although the overall roosting habitat (essentially badlands in prairie river valleys) of western small-footed bats is relatively secure, essential foraging habitat around riparian trees and springs is less secure. Construction of dams upstream and consequent reduced frequency and severity of natural flooding events can limit or prevent recruitment of cottonwoods (Populus sp.) resulting in the loss of riparian woodlands along prairie rivers. It is unlikely that riparian woodlands along the lower Red Deer River, for example, will regenerate, as a result of the Dickson Dam upriver of Red Deer (Cordes et al. 1997). Riparian areas might also be 
affected by overgrazing or conversion of river valley "flats" to irrigation cropland (Rood and Mahoney 1990). The importance of riparian woodlands to prairie bats has been widely recognized (Brigham 1993, Holloway and Barclay 2000). The loss of riparian woodlands is likely to negatively impact this species.

It is not clear what impact climate change will have on prairie bats. If the Canadian prairie climate continues to become drier with climate change, as predicted by Environment Canada (1997), bats hibernating in rock crevices may be burdened with additional evaporative water loss brought about by decreased humidity and increased temperatures (Kallen 1964). Because periodic winter flight of bats has been associated with dry climates (e.g., high altitude Nevada and New Mexico, southern Alberta prairies; summarized in Lausen and Barclay 2006), one response may be more frequent arousal and winter flights, placing greater strain on stored fat reserves; however, shorter winter seasons may occur, resulting in a shorter hibernation period thus balancing the changes that may occur in energy budgets. Alternatively, bats may be forced to seek other hibernation areas. In the Canadian prairies, where higher altitude refugia are not available, distributional ranges for bats may shift (Humphries et al. 2002). This shift may necessitate greater flight distances between summer and winter areas, and movement out of river valleys and through areas of unsuitable habitat patches, which may not be possible for western small-footed bats owing to their small size and poorer flight ability than other Alberta bat species. Predicted increase in prairie drought (Environment Canada 1997) will certainly put additional pressure on governments to dam and divert rivers (Schindler and Donahue 2006), and if damming occurred in the range of western small-footed bats, the associated habitat loss would likely have negative consequences for this species, as outlined above.

Wind energy development is on the increase in Canada (CanWEA 2008), and wind turbines cause bat fatalities (Arnett et al. 2008). While most wind-turbine bat fatalities across North America are the high-flying migratory species, other species (e.g., Myotis) have been reported to make up more than $20 \%$ of fatalities at several wind farms, including one site in southwestern Alberta (Arnett et al. 2008). To date, no turbines in Alberta have been built near riparian areas with known populations of western smallfooted bats; however, one wind farm located adjacent to Castle River (west of Pincher Creek) reported $23 \%$ of its fatalities to be little brown bats (Arnett et al. 2008). These Myotis fatalities suggest that wind developments might impact western small-footed bats if turbines were to be built near one of their main subpopulations. Prior to such a development, study of foraging western small-footed bats would be advisable to determine whether they forage at heights or distances from river valleys that would put them at risk.

\section{STATUS DESIGNATIONS*}

1. Alberta. - In 2005, the western small-footed bat was ranked as Sensitive because of the apparently clumped and disjunct distribution and lack of knowledge about the populations (Alberta Sustainable Resource Development 2007). It has had the equivalent general status rank since 1996 (Alberta Wildlife Management Division 1996, Alberta Sustainable Resource Development 2001).

The Alberta Natural Heritage Information Network (2007a) ranks western smallfooted bats as S2 in Alberta indicating that there are "6-20 occurrences" and that they "may be vulnerable to extirpation." Here the term occurrences refers to "main pockets of abundance," or discreet areas where this species is consistently found (W. Nordstrom, pers. comm.). These occurrences seem to refer to genetic subpopulations.

\footnotetext{
* See Appendix 1 for definitions of selected status designations.
} 
In Alberta, all bats are identified as "nonlicence animals" under the Alberta Wildlife Act and Wildlife Regulations. This designation means that bats can be hunted or harvested without a permit. However, hibernacula of all bats in Alberta are protected from disturbance between 1 September and 30 April and, for reasons of public health safety, a person may not be in possession of a live bat other than to temporarily capture and relocate it from one's property (Government of Alberta 2005).

2. Other Areas. - In British Columbia, western small-footed bats are ranked as "S2S3 Blue List." S2 identifies the species as "Imperiled" whereas S3 identifies it as being of "Special Concern." Blue-listed species are taxa that are at risk but not Extirpated, Endangered or Threatened (British Columbia Conservation Data Centre 2007). Saskatchewan ranks the species as S3B, SNRN (Saskatchewan Conservation Data Centre 2007), which indicates that the species may be at risk, but that the lack of knowledge of the animal in that province makes certain ranking impractical. The general status of the western small-footed bat is May Be at Risk in B.C. and Sensitive in Saskatchewan (CESCC 2006).

Globally, western small-footed bats are ranked G5 (NatureServe 2007) as there are probably over 100 occurrences and the species is demonstrably secure. It is not ranked in Montana (Montana Natural Heritage Program 2007) or Idaho (Idaho Fish and Game 2006), or the United States generally (United States Fish and Wildlife Service 2007).

\section{RECENT MANAGEMENT IN ALBERTA}

Although there has been no specific management of western small-footed bats in Alberta, there has been considerable research by Holloway (1998) and currently by Lausen, as described in this report. As a result, the knowledge available for management of the species in the province is greater than that available elsewhere.
Population size estimation and data upon which to evaluate population trends are lacking, but the stage has been set for these data to be collected; a large number of western small-footed bats has been banded in several regions of Alberta (approximately 700 individuals from 2002 to 2005; C. Lausen, unpubl. data), and therefore the opportunity exists to monitor in these areas. Such monitoring would have to begin soon to make best use of these marked individuals, given that the time between marking and resighting sessions needs to be minimized to produce best results for population estimation (O'Shea and Bogan 2003b).

Landscape-level habitat modeling done for western small-footed bats in the MULTISAR project (Quinlan et al. 2004, Landry 2004) required that basic spatial and temporal habitat selection and behaviour be known for western small-footed bats. Although basic information was gleaned from the literature and from preliminary results of C. Lausen's work at that time, habitat modeling should be revisited for this species once its dependency on riparian cottonwoods has been investigated.

\section{SYNTHESIS}

It is reasonable to assume that the paucity of early records of small-footed bats in Alberta was a consequence of the limits of the technology and effort rather than actual scarcity of the bats. Relative to little and big brown bats in southern Alberta, western small-footed bats have low reproductive rates and short dispersal distances. Gene flow among individuals is reduced at distances of greater than $150 \mathrm{~km}$ and stretches of unsuitable roosting habitat. Genetic relatedness indicates that this species is structured according to river valleys, suggesting it does not tend to venture far outside of them. Subpopulations of this species seem to occur disjunctly along rivers, corresponding to patches of suitable habitat. Both males and females return to their natal areas for the summer months, roosting in neighbourhoods 
of related individuals. Females generally select roosts that are in mudstone, are lower to the ground and are shallower than roosts of sympatric bat species. Still to be determined is whether this roost selection makes this species more vulnerable to disturbance/predation in areas where human populations are large.

There has been considerable research conducted on western small-footed bats in Alberta, so we now have information upon which to evaluate the conservation status of the species in Alberta. However, there are still important information gaps to fill. One area for further study is to determine if these animals occur upstream of the currently recognized distribution. Also, their abundance needs to be formally evaluated, as research efforts to date have not focused on population estimation and consequently have not used appropriate study designs for such estimation. Appropriate standardized protocols that can be used repeatedly over time to establish trends in relative abundances of all bats in prairie river valleys are needed.
In general, what is required is consistent and intense effort in several areas of the prairies to census and monitor trends using mark-recapture techniques (e.g., bands or PIT-tags; O'Shea and Bogan 2003b).

As riparian cottonwoods continue to disappear (Bradley and Smith 1986), wind-turbine developments that kill bats (Arnett et al. 2008, Barclay et al. 2007) increase in numbers on the Alberta prairies (AESO 2008), and drought puts additional pressure on governments to dam and divert rivers (Schindler and Donahue 2006), the prairie landscape is almost certain to change in a way that will influence bats. It is not clear how these potential threats may affect western small-footed bat populations in Alberta. Further investigations are needed to determine the value of riparian prairie river woodlands to western small-footed bats, the causes of bat fatalities by wind turbines, and the full distribution of western small-footed bats along southern Alberta rivers. 


\section{LITERATURE CITED}

Adams, R.A,. and K.M. Thibault. 2006. Temporal resource partitioning by bats at water holes. Journal of Zoology, London 270:466-472.

AESO. 2008. Alberta Electric System Operator. Wind Energy. http://www. aeso.ca/gridoperations/13902.html [Accessed: 5 Feb. 2008].

Alberta Natural Heritage Information Network. 2007a. Mammal Tracking List. Alberta Natural Heritage Information Centre (ANHIC). URL: http//www.cd.gov. ab.ca/preserving/parks/anhic/index. asp [Last updated 24 April 2007].

Alberta Natural Heritage Information Centre (ANHIC). 2007b.ExplanationofRanks. Alberta Tourism, Parks, Recreation and Culture. URL: http://tprc.alberta. ca/parks/heritageinfocentre/animals/ definitions.aspx. [Updated: 1 October 2007].

Alberta Sustainable Resource Development. 2001. The general status of Alberta wild species 2000. Alberta Sustainable Resource Development, Fish and Wildlife Service, Edmonton, AB. 44pp.

Alberta Sustainable Resource Development. 2005. Fish and Wildlife Management Information System. Accessible through - Alberta Sustainable Resource Development, Fisheries \& Wildlife Management Division, $2^{\text {nd }}$ Floor. Great West Life Bldg., 9920-108 St., Edmonton Alberta, T5K 2M4.

Alberta Sustainable Resource Development. 2007. The general status of Alberta wild species 2005. Alberta Sustainable Resource Development, Fish and
Wildlife Service http://www.srd.gov. $\mathrm{ab} . \mathrm{ca} / \mathrm{fw} /$ wildspecies/search.htm [Accessed 20 February 2007].

Alberta Wildlife Management Division. 1996. The status of Alberta wildlife. Alberta Environmental Protection, Wildlife Management Division, Edmonton, AB. 44 pp

Arnett, E.B., W.K. Brown, W.P. Erickson, J.K. Fiedler, B.L. Hamilton, T.H. Henry, A. Jain, G.D. Johnson, J. Kerns, R.R. Koford, C.P. Nicholson, T.J. OConnell, M.D. Piorkowski, and R. D. Tankersley, Jr. 2008. Patterns of bat fatalities at wind energy facilities in North America. Journal of Wildlife Management 72:61-78.

Banfield, A.W.F. 1974. The mammals of Canada. University of Toronto Press, Toronto. Xxv +438 pp. 113 pl.

Barbour, R.W., and W.H. Davis. 1969. Bats of America. University Press of Kentucky, Lexington, KT. 24 plates, 286 pp.

Barclay, R.M.R., J. Ulmer, C.J.A. MacKenzie, M.S. Thompson, L. Olson, J. McCool, E. Cropley, and G. Poll. 2004. Variation in the reproductive rate of bats. Canadian Journal of Zoolgy 82:688693.

Barclay, R.M.R., E.F. Baerwald, and J.C. Gruver. 2007. Variation in bat and bird fatalities at wind energy facilities: assessing the effects of rotor size and tower height. Canadian Journal of Zoology 85:381-387.

Beck, W.H. 1958. A guide to Saskatchewan mammals. Special publication no. 1. Saskatchewan Natural History Society, Regina. $52 \mathrm{pp}$. 
Bogan, M.A., J.G. Osborne, and J.A. Clarke. 1996. Observations on bats at Badlands National Park, South Dakota. Prairie Naturalist 28:115-123.

Bradley, C.E., and D.G. Smith. 1986. Plains cottonwood recruitment and survival on a prairie meandering river floodplain, Milk River, southern Alberta and northern Montana. Canadian Journal of Botany 64:1433-1442.

Brigham, R.M. 1993. Riparian habitat and its importance for roosting and foraging by bats. In: Riparian Habitat Management and Research (K.H. Morgan and M.A. Lashmar, eds.). pp. 57-72.

British Columbia Conservation Data Centre. 2007. Species Summary: Myotis ciliolabrum. B.C. Minist. of Environment. Available: http:// srmapps.gov.bc.ca/apps/eswp/ [Visited Accessed 23 Jan 2007].

CanWEA. 2008. Canadian Wind Energy Association. Wind Energy Sets Global Growth Record in 2007 -- Canada Expects a Record Year for New Installations in 2008. http://www. canwea.ca/news releases.cfm? ID $=58$. [Accessed: 5 Feb. 2008.]

CESCC. 2006. Wild Species 2005: The General Status of Species in Canada. Canadian Endangered Species Conservation Council.

Collister, D., and C. Hunt. 1990. Encounter with a small-footed bat (Myotis ciliolabrum) in the foothills of southwestern Alberta. Alberta Naturalist 20:105-106.

Cordes, L.D., F.M.R. Hughes, and M. Getty. 1997. Factors affecting the regeneration and distribution of riparian woodlands along a northern prairie river: the Red
Deer River, Alberta, Canada. Journal of Biogeography 24:675-695.

COSEWIC. 2006. Definitions and Abbreviations. Committee on the Status of Endangered Wildlife in Canada. URL: http://www.cosewic. gc.ca [Updated April 2006].

Cryan, P.M., M.A. Bogan, and J.S. Altenbach. 2000. Effect of elevation on distribution of female bats in the Black Hills, South Dakota. Journal of Mammalogy 81:719-725.

Dalquest, W.W. 1948. Mammals ofWashington. University of Kansas Publications, Museum of Natural History Vol 2, Lawrence KS, pp. 1-444, 140 fig.

Davis, R., and E.L. Cockrum. 1963. Bridges utilized as day-roosts by bats. Journal of Mammalogy 44:428-430.

Environment Canada. 1997. The Canada Country Study: Climate Impacts and Adaptation. Canadian Prairies Summary. Ottawa, Ontario. $10 \mathrm{pp}$.

Farney, J.P., and J.K. Jones, Jr. 1980. Notes on the natural history of bats from Badlands National Monument, South Dakota. Prairie Naturalist 12:9-12.

Fenton, M.B., C.G. van Zyll de Jong, G.P. Bell, D.B. Campbell, and M. Laplante. 1980. Distribution, parturition dates, and feeding of bats in south-central British Columbia. Canadian FieldNaturalist 94:416-420.

Foresman, K.R. 2001. The wild mammals of Montana. Special Publication No. 12 American Society of Mammalogists, Lawrence, KS. vii +278 pp. 
Garcia, P.F.J., S.A. Rasheed, and S.L. Holroyd. 1995. Status of the western smallfooted Myotis in British Columbia. Ministry of Environment, Lands and Parks, Wildlife Branch, Wildlife Working Report N. WR-74. 13pp.

Government of Alberta. 2002. Meridian Dam Preliminary Feasibility Study. http://www3.gov.ab.ca/env/water/ MeridianDam/ [Accessed 30 Nov. 2007].

Government of Alberta. 2005. Wildlife Act (Statutes of Alberta, 1984, Chapter W-10 with amendments in force as of 188/2005) and Wildlife Regulation (Alberta Regulation 143/97 with amendments up to and including Alberta Regulation 219/2007 and Alberta Regulation 2/2001). Queen's Printer for Alberta.

Greenwood, P.J. 1980. Mating systems, philopatry and dispersal in birds and mammals. Animal Behavior 28:11401162 .

Grindal, S.D., J.L. Morissette, and R.M. Brigham. 1999. Concentration of bat activity in riparian habitats over an elevational gradient. Canadian Journal of Zoology 77:972-977.

Hardy, R. 1941. Some notes on Utah bats. Journal of Mammalogy 22:289-295.

Hendricks, P., and B.A. Maxell. 2005. Bat Surveys on USFS Northern Region Lands in Montana: 2005. Report to the USDA Forest Service, Northern Region. Montana Natural Heritage Program, Helena, MT. 12 pp. plus appendices.

Hendricks, P., C. Currier, and J. Carlson. 2004. Bats of the BLM Billings Field
Office in south-central Montana, with emphasis on the Pryor Mountains. Report to Bureau of Land Management Billings Field office. Montana Natural Heritage Program, Helena, MT. 19 pp. + appendices.

Hendricks, P., S. Lenard, C. Currier, and J. Johnson. 2005. Bat use of highway bridges in south-central Montana. Report prepared for: Montana Department of Transportation Research Programs, Helena, MT. iv. + 31. 16 Fig, 8 Tables.

Holloway, G.L. 1998. The ecology of prairiedwelling bats in southeastern Alberta. Master of Science thesis, University of Calgary, Alberta, Canada, 100 pp.

Holloway, G.L., and R.M.R. Barclay. 2000. Importance of prairie riparian zones to bats in southeastern Alberta. Ecoscience 7:115-122.

Holloway, G.L., and R.M.R. Barclay. 2001. Myotis ciliolabrum. Mammalian Species No. 670. pp. 1-5, 3 figs.

Humphries, M.M., D.W. Thomas, and J.R. Speakman. 2002. Climate-mediated energetic constraints on the distribution of hibernating mammals. Nature 418:313-316.

Idaho Fish and Game. 2006. Idaho Conservation Data Centre. URL: http://fishandgame. idaho.gov/cms/tech/cdc/te.cfm. [Accessed 23 January 2007].

Jones, E.T. 1974. Sixteen Alberta bat records, 1971-1974. Blue Jay 32:244-245.

Jones, J.K., Jr. 1964. Distribution and taxonomy of mammals of Nebraska. University of Kansas Publications Museum of Natural History 16:1-356. 
Kallen, F.C. 1964. Some aspects of water balance in hibernating bats. Annales Academiæ Scientiarum Fennicæ of Science (Series A IV) 71:257-268.

Koford, C.B., and M.R. Koford. 1948. Breeding colonies of bats, Pipistrellus Hesperus and Myotis subulatus melanorhinus. Journal of Mammalogy 29:417-418.

Kuenzi,A.J., G.T. Downard, and M.L. Morrison. 1999. Bat distribution and hibernacula use in west central Nevada. Great Basin Naturalist 59:213-220.

Kunz, T.H. 2003. Censusing bats: Challenges, solutions and sampling biases. In: Monitoring trends in bat populations of the United States and Territories: Problems and Prospects. (O'Shea, T.J. and M.A. Bogan, eds.) U.S. Geological Survey, Biological Resources Discipline, Information and Technology Report, pp. 9-19.

Landry, J. 2004. Western small-footed Myotis (Myotis ciliolabrum ciliolabrum). In: MULTISAR: The Milk River Basin Project. Habitat suitability models for selected wildlife management species (Downey, B.A., B.L. Downey, R.W. Quinlan, O. Castelli, V.J. Remesz and P.F. Jones, eds.). Alberta Sustainable Resource Management, Fish and Wildlife Division, Species at Risk Report No. 86. Edmonton, AB, pp. 90 97.

Lausen, C.L. 2001. Thermoregulation and roost selection by reproductive big brown bats (Eptesicus fuscus) roosting in the South Saskatchewan River Valley, Alberta: rock-roosting and building-roosting colonies. MSc. Thesis, University of Calgary, Calgary, Alberta. 119 pp.
Lausen, C.L. 2006. 2005-2006 bat survey of the middle Red Deer and Battle rivers. Unpublished report prepared for Alberta Natural Heritage Information Centre, Parks and Protected Areas Division, $2^{\text {nd }}$ Floor, Oxbridge Place 9820 - 106 St., Edmonton, AB. iv + 22 pp. 2 fig 4 tables.

Lausen, C.L. 2007. Roosting Ecology and Landscape Genetics of Prairie Bats. $\mathrm{PhD}$ Dissertation, University of Calgary, Calgary, AB. 271 pp.

Lausen, C. L. and R.M.R. Barclay. 2002. Roosting behaviour and roost selection of female big brown bats (Eptesicus fuscus) roosting in rock crevices in southeastern Alberta. Canadian Journal of Zoology 80:1069-1076.

Lausen, C.L., and R.M.R. Barclay. 2006. Winter bat activity in the Canadian prairies. Canadian Journal of Zoology 84:1079-1086.

Lausen, C.L., I. Delisle, R.M.R. Barclay, and C. Strobeck. In preparation a. Beyond mtDNA: nuclear gene flow confutes cryptic species of little brown bats $(M$. lucifugus).

Lausen, C.L., T.D. Pretzlaw and R.M.R. Barclay. In preparation $b$. Roosting ecology of the western small-footed (Myotis ciliolabrum) and big brown (Eptesicus fuscus) bats in the Canadian prairies. A version of this manuscript can be found as Chapter $2 I n$ : Lausen, C.L. 2007. Roosting Ecology and Landscape Genetics of Prairie Bats. $\mathrm{PhD}$ Dissertation, University of Calgary, Calgary, AB, pp. 28-68.

Merriam, C.H. 1886. Description of a new species of bat from the western United States (Vespertilo ciliolabrum sp. nov.). 
Proceedings of the Biological Society of Washington 4:1-4.

Montana Natural Heritage Program. 2007. http://nhp.nris.state.mt.us/ SpeciesOfConcern/ [Accessed 23 January 2007].

Nagorsen, D.W., and R.M. Brigham. 1993. Bats of British Columbia. Royal British Columbian Museum Handbook, University of British Columba Press, Vancouver, BC. 164 pp.

National Research Council. 1995. Science and the Endangered Species Act. National Academy Press, Washington, DC. 271 pp.

NatureServe. 2007. NatureServe Explorer: An online encyclopedia of life [web application]. Version 6.2. NatureServe, Arlington, Virginia. Available http:// www.natureserve.org/explorer. [Accessed: November 23, 2007].

Navo, K.W., S.G. Henry, and T.E. Ingersoll. 2002. Observations of swarming by bats and band recoveries in Colorado. Western North American Naturalist 62: 124-126.

Nero, R.W. 1958. A new Saskatchewan bat. The Blue Jay 16:175.

Nero, R.W. 1959. Some recent mammal records. The Blue Jay 17:169,173.

O'Shea, T.J., and M.A. Bogan. 2003a. Introduction. In: Monitoring trends in bat populations of the United States and Territories: Problems and Prospects. (O’Shea, T.J. and M.A. Bogan, eds.) U.S. Geological Survey, Biological Resources Discipline, Information and Technology Report, pp. $1-7$.
O'Shea, T.J., and M.A. Bogan. $2003 \mathrm{~b}$. Monitoring trends in bat populations of the United States and Territories: Problems and Prospects. U.S. Geological Survey, Biological Resources Discipline, Information and Technology Report. 274 pp.

Pattie, D., and C. Fisher. 1999. Mammals of Alberta. Lone Pine Publishing, Edmonton, AB. 240 pp.

Quay, W.B. 1948. Notes on some bats from Nebraska and Wyoming. Journal of Mammalogy 29:181-182.

Pierson, D. 1998. Tall trees, deep holes, and scarred landscapes. In: Bat Biology and Conservaton (T.H. Kunz and P.A. Racey, eds.). Smithsonian Institution Press, Washington, D.C., pp. 309-325.

Quinlan, R., P. Jones, B. Downey, B. Downey, T. Clayton, and B. Taylor. 2004. MULTISAR: a conservation strategy for species at risk in the Milk River Basin. In: Proceedings of the $7^{\text {th }}$ Prairie Conservation and Endangered Species Conference (G.C. Trottier, E. Anderson, M. Steinhilber, eds.). Natural History Occasional Paper No. 26, Provincial Museum of Alberta, Edmonton, pp. 37-40.

Rand, A.L. 1948. Mammals of the eastern Rockies and western plains of Canada. National Museum of Canada Bulletin No. 108. Ottawa, ON. 237 pp.

Ricklefs, R.E. 1990. Ecology, $3^{\text {rd }}$ edn. W.H. Freeman and Company, New York, NY. 896 pp.

Robbins, L.W., M.D. Engstrom, R.B. Wilhelm, and J.R. Choate. 1977. Ecogeographic status of Myotis leibii in Kansas. Mammalia 41:365-467. 
Rood, S.B., and J.M. Mahoney. 1990. Collapse of riparian poplar forest downstream from dams in western prairies: Probable causes and prospects for mitigation. Environmental Management 14:451464.

Royal Alberta Museum. 2007. Collections database http://www. royalalbertamuseum.ca/collect/intro. htm . [Accessed 20 January 2007].

Saskatchewan Conservation Data Centre. 2007. http://www.biodiversity.sk.ca/Docs/ verts.pdf (Last updated 9/12/2005)

Schindler, D.W., and W.F. Donahue. 2006. An impending water crisis in Canada's western prairie provinces. Proceedings of the National Academy of Science, U.S.A. 103:7210-7216.

Schowalter, D.B, and A. Allen. 1981. Late summer activity of small-footed, longeared, and big brown bats in Dinosaur Park, Alberta. Blue Jay 39:50-53.

Smith, H.C. 1993. Alberta Mammals: an atlas and guide. The Provincial Museum of Alberta, Edmonton, AB. xii +239 pp.

Smith, H.C., and D.B. Schowalter. 1979. A subspecies of little brown bat new to the province of Alberta. Blue Jay 37:58-63.

Soper, J.D. 1964. The mammals of Alberta. Hamly Press Ltd. Edmonton, AB 412 pp.

Stephens, T.C. 1945. Say's bat in Nebraska. Journal of Mammalogy 26:92.
Swenson, J.E. 1970. Notes on distribution of Myotis leibii in eastern Montana. Blue Jay 28:173-174.

Swenson, J.E., and G.F. Shanks. 1979. Noteworthy records of bats from northeastern Montana. Journal of Mammalogy 60:650-652.

Tuttle, M.D., and L.R. Heaney. 1974. Maternity habits of Myotis leibii in South Dakota. Bulletin Southern California Academy of Sciences 73:80-83.

United States Fish and Wildlife Service. 2007. Species Information. Threatened and endangered animals and plants. http:// www.fws.gov/Endangered/wildlife. html Visited 23 January 2007

van Zyll de Jong, C.G. 1984. Taxonomic relationships of Nearctic smallfooted bats of the Myotis leibii group (Chiroptera: Vespertilionidae). Canadian Journal of Zoology 62:2592526.

van Zyll de Jong, C.G. 1985. Handbook of Canadian mammals 2: Bats. National Museum of Natural Sciences, National Museums of Canada Ottawa, ON. 211 pp.

Wilkinson, G.S., and J.M. South. 2002. Life history, ecology and longevity in bats. Aging Cell 1:124-131.

Woodsworth, G.C. 1981. Spatial partitioning by two species of sympatric bats, Myotis californicus and Myotis leibii. M.Sc. thesis, Carleton University, Ottawa, Ontario. 68 pp. 
Appendix 1: Definitions of status ranks and legal designations.

A. The General Status of Alberta Wild Species 2005 (after Alberta Sustainable Resource Development 2007)

\begin{tabular}{|l|l|l|}
\hline 2005 Rank & 1996 Rank & Definitions \\
\hline At Risk & Red & $\begin{array}{l}\text { Any species known to be } \text { At Risk after formal detailed status } \\
\text { assessment and designation as Endangered } \text { or Threatened in } \\
\text { Alberta. }\end{array}$ \\
\hline May Be At Risk & Blue & $\begin{array}{l}\text { Any species that may be at risk of extinction or extirpation, and is } \\
\text { therefore a candidate for detailed risk assessment. }\end{array}$ \\
\hline Sensitive & Yellow & $\begin{array}{l}\text { Any species that is not at risk of extinction or extirpation but may } \\
\text { require special attention or protection to prevent it from becoming at } \\
\text { risk. }\end{array}$ \\
\hline Secure & Green & $\begin{array}{l}\text { Any species that is not } \text { At Risk, May Be At Risk } \text { or Sensitive. } \\
\text { is available to reliably evaluate its general status. }\end{array}$ \\
\hline Undetermined & $\begin{array}{l}\text { Status } \\
\text { Undetermined }\end{array}$ & Any species that has not been examined during this exercise. \\
\hline Not Assessed & $\mathrm{n} / \mathrm{a}$ & Any species that has been introduced as a result of human activities. \\
\hline Exotic/Alien & $\mathrm{n} / \mathrm{a}$ & $\begin{array}{l}\text { Any species no longer thought to be present in Alberta (Extirpated) } \\
\text { or no longer believed to be present anywhere in the world (Extinct). }\end{array}$ \\
\hline Extirpated/Extinct & $\mathrm{n} / \mathrm{a}$ & $\begin{array}{l}\text { Any species occurring infrequently and unpredictably in Alberta, } \\
\text { i.e., outside its usual range. }\end{array}$ \\
\hline Accidental/Vagrant & $\mathrm{n} / \mathrm{a}$ &
\end{tabular}

\section{B. Alberta Species at Risk Formal Status Designations}

Species designated as Endangered under Alberta's Wildlife Act include those listed as Endangered or

Threatened in the Wildlife Regulation (in bold).

\begin{tabular}{|l|l|}
\hline Endangered & A species facing imminent extirpation or extinction. \\
\hline Threatened & A species likely to become endangered if limiting factors are not reversed. \\
\hline $\begin{array}{l}\text { Species of } \\
\text { Special Concern }\end{array}$ & $\begin{array}{l}\text { A species of special concern because of characteristics that make it particularly sensitive to } \\
\text { human activities or natural events. }\end{array}$ \\
\hline Data Deficient & A species for which there is insufficient scientific information to support status designation. \\
\hline
\end{tabular}

\section{Committee on the Status of Endangered Wildlife in Canada (after COSEWIC 2006)}

\begin{tabular}{|l|l|}
\hline Extinct & A species that no longer exists. \\
\hline Extirpated & A species that no longer exists in the wild in Canada, but occurs elsewhere. \\
\hline Endangered & A species facing imminent extirpation or extinction. \\
\hline Threatened & A species that is likely to become endangered if limiting factors are not reversed. \\
\hline Special Concern & $\begin{array}{l}\text { A species that may become threatened or endangered because of a combination of } \\
\text { biological characteristics and identified threats. }\end{array}$ \\
\hline Not at Risk & $\begin{array}{l}\text { A species that has been evaluated and found to be not at risk of extinction given the } \\
\text { current circumstances. }\end{array}$ \\
\hline Data Deficient & $\begin{array}{l}\text { A category that applies when the available information is insufficient to (a) resolve a } \\
\text { wildlife species' eligibility for assessment, or (b) permit an assessment of the wildlife } \\
\text { species' risk of extinction. }\end{array}$ \\
\hline
\end{tabular}


D. Heritage Status Ranks: Global (G), National (N), Sub-national (S) (after Alberta Natural Heritage Information Centre 2007b, NatureServe 2007)

\begin{tabular}{|l|l|}
\hline G1/N1/S1 & $\begin{array}{l}5 \text { or fewer occurrences or only a few remaining individuals. May be especially vulnerable } \\
\text { to extirpation because of some factor of its biology. }\end{array}$ \\
\hline G2/N2/S2 & $\begin{array}{l}6 \text { to } 20 \text { or fewer occurrences or with many individuals in fewer locations. May be especially } \\
\text { vulnerable to extirpation because of some factor of its biology. }\end{array}$ \\
\hline G3/N3/S3 & $\begin{array}{l}21 \text { to } 100 \text { occurrences; may be rare and local throughout its range, or in a restricted range } \\
\text { (may be abundant in some locations). May be susceptible to extirpation because of large- } \\
\text { scale disturbances. }\end{array}$ \\
\hline G4/N4/S4 & Typically > 100 occurrences. Apparently secure. \\
\hline G5/N5/S5 & Typically > 100 occurrences. Demonstrably secure. \\
\hline GX/NX/SX & Believed to be extinct or extirpated; historical records only. \\
\hline GH/NH/SH & Historically known; may be relocated in the future. \\
\hline G?/N?/S? & Not yet ranked, or rank tentatively assigned. \\
\hline
\end{tabular}

E. United States Endangered Species Act (after National Research Council 1995)

\begin{tabular}{|l|l|}
\hline Endangered & Any species that is in danger of extinction throughout all or a significant portion of its range. \\
\hline Threatened & $\begin{array}{l}\text { Any species that is likely to become an endangered species within the foreseeable future } \\
\text { throughout all or a significant portion of its range. }\end{array}$ \\
\hline
\end{tabular}


Appendix 2: Percentage of total bat captures (Total Caps) that were western small-footed bats (WSF) are listed for each year. All locations are in southern Alberta, contain some degree of suitable roosting habitat for western small-footed bats, and are listed generally from north to south and west to east (see Figure 1 for locations). Unless otherwise indicated, captures are by C. Lausen and were made during general mist-netting sessions (see Notes).

\begin{tabular}{|c|c|c|c|c|c|}
\hline RIVER & LOCATION & YEAR & $\begin{array}{l}\text { PERCENT } \\
\text { WSF (\%) }\end{array}$ & $\begin{array}{l}\text { TOTAL } \\
\text { CAPS. }\end{array}$ & NOTES \\
\hline \multirow{3}{*}{ Battle River } & $\begin{array}{l}\text { Big Knife Provincial } \\
\text { Park }\end{array}$ & 2005 & 0 & 37 & \\
\hline & $\begin{array}{l}\text { Donalda (on } \\
\text { Meeting Creek) }\end{array}$ & 2005 & 0 & 4 & $\begin{array}{l}\text { Western small-footed bats } \\
\text { were targeted. }\end{array}$ \\
\hline & & 2006 & 0 & 22 & $\begin{array}{l}\text { Western small-footed bats } \\
\text { were targeted. }\end{array}$ \\
\hline \multirow[t]{9}{*}{ Red Deer } & $\begin{array}{l}\text { McKenzie Crossing } \\
\text { Recreation Area }\end{array}$ & 2005 & 0 & 11 & \\
\hline & $\begin{array}{l}\text { Dry Island Buffalo } \\
\text { Jump Provincial } \\
\text { Park }\end{array}$ & 2002 & 0 & 3 & \\
\hline & & 2005 & 25 & 32 & \\
\hline & $\begin{array}{l}\text { Drumheller - } \\
\text { Rosedale area }\end{array}$ & 2002 & 20 & 5 & \\
\hline & & 2004 & 28 & 179 & \\
\hline & $\begin{array}{l}\text { Dinosaur Provincial } \\
\text { Park }\end{array}$ & 2001 & 32 & 37 & \\
\hline & & 2002 & 74 & 133 & \\
\hline & & 2003 & 62 & 29 & \\
\hline & & 2004 & 35 & 534 & \\
\hline \multirow[t]{2}{*}{$\begin{array}{l}\text { Red Deer/South } \\
\text { Saskatchewan } \\
\text { Confluence }\end{array}$} & Near Empress & 2001 & 20 & 5 & \\
\hline & & 2004 & 3 & 37 & $\begin{array}{l}\text { Happened to net near little } \\
\text { brown bat night roost. }\end{array}$ \\
\hline \multirow{11}{*}{$\begin{array}{c}\text { South } \\
\text { Saskatchewan }\end{array}$} & Highway 41 & & & & \\
\hline & Crossing & $\frac{2001}{2002}$ & $\begin{array}{l}61 \\
80\end{array}$ & $\frac{93}{10}$ & \\
\hline & $\begin{array}{l}\text { Pipeline and Ferry } \\
\text { Crossings }\end{array}$ & 2001 & 47 & 318 & \\
\hline & $\begin{array}{l}\text { (<20 km north of } \\
\text { C.F.B. Suffield) }\end{array}$ & 2002 & 54 & 246 & $\begin{array}{l}\text { Western small-footed bats } \\
\text { were targeted. }\end{array}$ \\
\hline & & 2004 & 40 & 107 & \\
\hline & $\begin{array}{l}\text { Across river from } \\
\text { C.F.B. Suffield }\end{array}$ & 2001 & 75 & 8 & \\
\hline & & 2002 & 77 & 26 & \\
\hline & & 2003 & 14 & 7 & Big brown bats were targeted. \\
\hline & & 2004 & 49 & 37 & \\
\hline & Bow Island & 2002 & 50 & 12 & $\begin{array}{l}\text { Western small-footed bats } \\
\text { were targeted. }\end{array}$ \\
\hline & & 2003 & 34 & 96 & $\begin{array}{l}\text { Western small-footed bats } \\
\text { were targeted. }\end{array}$ \\
\hline
\end{tabular}


Appendix 2 cont.

\begin{tabular}{|c|c|c|c|c|c|}
\hline \multirow{2}{*}{ Old Man River } & \multirow[t]{2}{*}{$\begin{array}{l}\text { Along the river } \\
\text { north of Pincher } \\
\text { Station }\end{array}$} & 2006 & 0 & 141 & \multirow{2}{*}{$\begin{array}{l}\text { Data from a general river } \\
\text { valley survey by Erin } \\
\text { Baerwald. } \\
\text { This was from a general river } \\
\text { valley survey by Erin } \\
\text { Baerwald (pers. comm.). }\end{array}$} \\
\hline & & 2007 & 0 & $\sim 70$ & \\
\hline \multirow[t]{8}{*}{ Milk River } & \multirow[t]{5}{*}{$\begin{array}{l}\text { Writing on Stone } \\
\text { Provincial Park and } \\
\text { immediate area }\end{array}$} & 1987 & 8 & 278 & $\begin{array}{l}\text { Matt Saunders' data - } \\
\text { targeted western long-eared } \\
\text { bats in and around park } \\
\text { (pers.comm.) }\end{array}$ \\
\hline & & 1988 & 6 & 291 & $\begin{array}{l}\text { Matt Saunders' data - } \\
\text { targeted western long-eared } \\
\text { bats in and around park } \\
\text { (pers. comm.). }\end{array}$ \\
\hline & & 2001 & 0 & 37 & $\begin{array}{l}\text { Netted in vicinity of little } \\
\text { brown maternity roost. }\end{array}$ \\
\hline & & 2002 & 0 & 12 & $\begin{array}{l}\text { Netted in vicinity of little } \\
\text { brown maternity roost }\end{array}$ \\
\hline & & 2003 & 3 & 90 & $\begin{array}{l}\text { General netting within park } \\
\text { boundaries. }\end{array}$ \\
\hline & \multirow[t]{3}{*}{$\begin{array}{l}\text { Pinhorn Grazing } \\
\text { Reserve }\end{array}$} & 2002 & 61 & 85 & \\
\hline & & 2003 & 42 & 45 & \\
\hline & & 2004 & 42 & 60 & \\
\hline
\end{tabular}




\section{List of Titles in This Series}

(as of March 2008)

No. 1 Status of the Piping Plover (Charadrius melodus) in Alberta, by David R. C. Prescott. 19 pp. (1997)

No. 2 Status of the Wolverine (Gulo gulo) in Alberta, by Stephen Petersen. 17 pp. (1997)

No. 3 Status of the Northern Long-eared Bat (Myotis septentrionalis) in Alberta, by M. Carolina Caceres and M. J. Pybus. 19 pp. (1997)

No. 4 Status of the Ord's Kangaroo Rat (Dipodomys ordii) in Alberta, by David L. Gummer. 16 pp. (1997)

No. 5 Status of the Eastern Short-horned Lizard (Phrynosoma douglassii brevirostre) in Alberta, by Janice D. James, Anthony P. Russell and G. Lawrence Powell. 20 pp. (1997)

No. 5 Update 2004. Status of the Short-horned Lizard (Phrynosoma hernandesi) in Alberta. Alberta Sustainable Resource Development. 27 pp. (2004)

No. 6 Status of the Prairie Rattlesnake (Crotalus viridis viridis) in Alberta, by Sheri M. Watson and Anthony P. Russell. 26 pp. (1997)

No. 7 Status of the Swift Fox (Vulpes velox) in Alberta, by Susan E. Cotterill. 17 pp. (1997)

No. 8 Status of the Peregrine Falcon (Falco peregrinus anatum) in Alberta, by Petra Rowell and David P. Stepnisky. 23 pp. (1997)

No. 9 Status of the Northern Leopard Frog (Rana pipiens) in Alberta, by Greg Wagner. 46 pp. (1997)

No. 9 Update 2003. Status of the Northern Leopard Frog (Rana pipiens) in Alberta. Alberta Sustainable Resource Development. 61 pp. (2003)

No. 10 Status of the Sprague's Pipit (Anthus spragueii) in Alberta, by David R. C. Prescott. 14 pp. (1997)

No. 11 Status of the Burrowing Owl (Speotyto cunicularia hypugaea) in Alberta, by Troy I. Wellicome. 21 pp. (1997)

No. 11 Update 2005. Status of the Burrowing Owl (Athene cunicularia) in Alberta. Alberta Sustainable Resource Development and Alberta Conservation Association. 28 pp. (2005)

No. 12 Status of the Canadian Toad (Bufo hemiophrys) in Alberta, by Ian M. Hamilton, Joann L. Skilnick, Howard Troughton, Anthony P. Russell, and G. Lawrence Powell. 30 pp. (1998)

No. 13 Status of the Sage Grouse (Centrocercus urophasianus urophasianus) in Alberta, by Cameron L. Aldridge. 23 pp. (1998)

No. 14 Status of the Great Plains Toad (Bufo cognatus) in Alberta, by Janice D. James. 26 pp. (1998)

No. 15 Status of the Plains Hognose Snake (Heterodon nasicus nasicus) in Alberta, by Jonathan Wright and Andrew Didiuk. 26 pp. (1998)

No. 16 Status of the Long-billed Curlew (Numenius americanus) in Alberta, by Dorothy P. Hill. 20 pp. (1998)

No. 17 Status of the Columbia Spotted Frog (Rana luteiventris) in Alberta, by Janice D. James. 21 pp. (1998) 
No. 18 Status of the Ferruginous Hawk (Buteo regalis) in Alberta, by Josef K. Schmutz. 18 pp. (1999)

No. 18 Update 2006. Status of the Ferruginous Hawk (Buteo regalis) in Alberta. Alberta Sustainable Resource Development and Alberta Conservation Association. 22 pp. (2006)

No. 19 Status of the Red-tailed Chipmunk (Tamias ruficaudus) in Alberta, by Ron Bennett. 15 pp. (1999)

No. 20 Status of the Northern Pygmy Owl (Glaucidium gnoma californicum) in Alberta, by Kevin C. Hannah. 20 pp. (1999)

No. 21 Status of the Western Blue Flag (Iris missouriensis) in Alberta, by Joyce Gould. 22 pp. (1999)

No. 21 Update 2005. Status of the Western Blue Flag (Iris missouriensis) in Alberta. Alberta Sustainable Resource Development and Alberta Conservation Association. 29 pp. (2005)

No. 22 Status of the Long-toed Salamander (Ambystoma macrodactylum) in Alberta, by Karen L. Graham and G. Lawrence Powell. 19 pp. (1999)

No. 23 Status of the Black-throated Green Warbler (Dendroica virens) in Alberta, by Michael R. Norton. 24 pp. (1999)

No. 24 Status of the Loggerhead Shrike (Lanius ludovicianus) in Alberta, by David R. C. Prescott and Ronald R. Bjorge. 28 pp. (1999)

No. 25 Status of the Plains Spadefoot (Spea bombifrons) in Alberta, by Richard D. Lauzon. 17 pp. (1999)

No. 26 Status of the Trumpeter Swan (Cygnus buccinator) in Alberta, by M. Lynne James. 21 pp. (2000)

No. 27 Status of the Pygmy Whitefish (Prosopium coulteri) in Alberta, by William C. Mackay. 16 pp. (2000)

No. 28 Status of the Short-eared Owl (Asio flammeus) in Alberta, by Kort M. Clayton. 15 pp. (2000)

No. 29 Status of the Willow Flycatcher (Empidonax traillii) in Alberta, by Bryan Kulba and W. Bruce McGillivray. 15 pp. (2001)

No. 30 Status of the Woodland Caribou (Rangifer tarandus caribou) in Alberta, by Elston Dzus. 47 pp. (2001)

No. 31 Status of the Western Spiderwort (Tradescantia occidentalis) in Alberta, by Bonnie Smith. 12 pp. (2001)

No. 32 Status of the Bay-breasted Warbler (Dendroica castanea) in Alberta, by Michael Norton. 21 pp. (2001)

No. 33 Status of the Cape May Warbler (Dendroica tigrina) in Alberta, by Michael Norton. 20 pp. (2001)

No. 34 Status of the Whooping Crane (Grus americana) in Alberta, by Jennifer L. White. 21 pp. (2001)

No. 35 Status of Soapweed (Yucca glauca) in Alberta, by Donna Hurlburt. 18 pp. (2001)

No. 36 Status of the Harlequin Duck (Histrionicus histrionicus) in Alberta, by Beth MacCallum. 38 pp. (2001)

No. 37 Status of the Grizzly Bear (Ursus arctos) in Alberta, by John L. Kansas. 43 pp. (2002)

No. 38 Status of the Wood Bison (Bison bison athabascae) in Alberta, by Jonathan A. Mitchell and C. Cormack Gates. 32 pp. (2002) 
No. 39 Status of the Bull Trout (Salvelinus confluentus) in Alberta, by John R. Post and Fiona D. Johnston. 40 pp. (2002)

No. 40 Status of the Banff Springs Snail (Physella johnsoni) in Alberta, by Dwayne A.W. Lepitzki. 29 pp. (2002)

No. 41 Status of the Shortjaw Cisco (Coregonus zenithicus) in Alberta, by Mark Steinhilber. 23 pp. (2002)

No. 42 Status of the Prairie Falcon (Falco mexicanus) in Alberta, by Dale Paton. 28 pp. (2002)

No. 43 Status of the American Badger (Taxidea taxus) in Alberta, by Dave Scobie. 17 pp. (2002)

No. 44 Status of the Yucca Moth (Tegeticula yuccasella) in Alberta. Alberta Sustainable Resource Development. $21 \mathrm{pp} .(2002)$

No. 45 Status of the White-winged Scoter (Melanitta fusca deglandi) in Alberta. Alberta Sustainable Resource Development. 15 pp. (2002)

No. 46 Status of the Lake Sturgeon (Acipenser fulvescens) in Alberta. Alberta Sustainable Resource Development. 30 pp. (2002)

No. 47 Status of the Western Silvery Minnow (Hybognathus argyritis) in Alberta. Alberta Sustainable Resource Development. 24 pp. (2003)

No. 48 Status of the Small-flowered Sand Verbena (Tripterocalyx micranthus) in Alberta. Alberta Sustainable Resource Development. 24 pp. (2003)

No. 49 Status of the Brown Creeper (Certhia americana) in Alberta. Alberta Sustainable Resource Development. 30 pp. (2003)

No. 50 Status of the Mountain Plover (Charadrius montanus) in Alberta. Alberta Sustainable Resource Development. 25 pp. (2003)

No. 51 Status of the St. Mary Shorthead Sculpin (provisionally Cottus bairdi punctulatus) in Alberta. Alberta Sustainable Resource Development. 24 pp. (2003)

No. 52 Status of the Stonecat (Noturus flavus) in Alberta. Alberta Sustainable Resource Development. 22 pp. (2003)

No. 53 Status of the Sage Thrasher (Oreoscoptes montanus) in Alberta. Alberta Sustainable Resource Development. 23 pp. (2004)

No. 54 Status of the Tiny Cryptanthe (Cryptantha minima) in Alberta. Alberta Sustainable Resource Development. 39 pp. (2004)

No. 55 Status of the Slender Mouse-ear-cress (Halimolobos virgata) in Alberta. Alberta Sustainable Resource Development. 27 pp. (2005)

No. 56 Status of the Barred Owl (Strix varia) in Alberta. Alberta Sustainable Resource Development. 15 pp. (2005)

No. 57 Status of the Arctic Grayling (Thymallus arcticus) in Alberta. Alberta Sustainable Resource Development. 41 pp. (2005)

No. 58 Status of the Weidemeyer's Admiral (Limenitis weidemeyerii) in Alberta. Alberta Sustainable Resource Development and Alberta Conservation Association. 13 pp. (2005) 
No. 59 Status of the Porsild's Bryum (Bryum porsildii) in Alberta. Alberta Sustainable Resource Development and Alberta Conservation Association. 30 pp. (2006)

No. 60 Status of the Western Grebe (Aechmophorus occidentalis) in Alberta. Alberta Sustainable Resource Development and Alberta Conservation Association. 29 pp. (2006)

No. 61 Status of the Westslope Cutthroat Trout (Oncorhynchus clarkii lewisii) in Alberta. Alberta Sustainable Resource Development and Alberta Conservation Association. 34 pp. (2006)

No. 62 Status of the Limber Pine (Pinus flexilis) in Alberta. Alberta Sustainable Resource Development and Alberta Conservation Association. 17 pp. (2007)

No. 63 Status of the Whitebark Pine (Pinus albicaulis) in Alberta. Alberta Sustainable Resource Development and Alberta Conservation Association. 22 pp. (2007)

No. 64 Status of the Western Small-footed Bat (Myotis ciliolabrum) in Alberta. Alberta Sustainable Resource Development and Alberta Conservation Association. 24 pp. (2008) 
LIBRARY AND ARCHIVES CANADA Bibliothèque et Archives Canada 